\title{
Skin Scrape Test: An Inexpensive and Painless Skin Test For Recognition Of Immediate Hypersensitivity In Children And Adults
}

\author{
Celso Eduardo Olivier ${ }^{1,2, *}$, Daiana Guedes Pinto Argentão², Raquel Acácia Pereira Gonçalves dos \\ Santos ${ }^{2}$, Mariana Dias da Silva ${ }^{2}$, Regiane Patussi Santos Lima ${ }^{2}$ and Ricardo de Lima Zollner ${ }^{1}$ \\ ${ }^{1}$ Discipline and Laboratory of Clinical Immunology, Department of Internal Medicine, Faculty of Medical Sciences, \\ University of Campinas, São Paulo, Brazil \\ ${ }^{2}$ Instituto Alergoimuno de Americana - São Paulo - Brazil
}

\begin{abstract}
Background: Skin testing is a mainstay in allergology, and its importance is increasing in several fields. The ability to choose the most suitable technique according to the clinical setting is an advantage for the medical team.

Objectives: To describe in detail an alternative technique of the coetaneous allergy test (skin scrape test) conceived as a variation of the former skin scratch test; to evaluate its value as a tool for diagnosis of immune sensitization; and to compare its accuracy with the skin prick test.

Methods: The skin scrape test and skin prick test were performed side by side with the same allergen extracts in $162 \mathrm{hu}-$ man subjects classified in two groups according to the known presence or absence of serum specific-IgE to these allergens.

Results: The sensitivity of the skin scrape test to detect immediate reactions was $85.0 \%$. The sensitivity of the skin prick test was $86.5 \%$. The sensitivity of both techniques analyzed together as a unique procedure was $94.2 \%$. The specificity of the skin scrape test was $90.1 \%$.The specificity of the skin prick test was $72.9 \%$.The specificity of both tests analyzed together as a unique procedure was $70.5 \%$.

Conclusions: The skin scrape test is an alternative and complementary technique for allergic skin testing, and it is able to detect IgE-specific immune sensitization without the disadvantages of the skin scratch test. The skin scrape test has similar outcomes to the skin prick test.
\end{abstract}

Keywords: Immediate Hypersensitivity (Medline ID D006969), Diagnosis (Medline ID D003933), Skin Test (Medline ID D012882), Dermatophagoides Antigens (Medline ID D039741), Child (Medline ID D002648), Atopic Dermatitis (Medline ID D003876), Rhinitis (Medline ID D012220), Asthma (Medline ID D001249).

\section{INTRODUCTION}

The skin scratch test was the first test described as a tool for allergy diagnosis. It was reported in 1873 by Charles Blackley, who abraded a quarter-inch area of his own forearm to correlate his nasal symptoms with Lolium italicum pollen grains [1]. After Blackley's initiative, skin scratch tests were used during a long period until the appearance of the skin prick test(SPT) in the early 1950s [2], which, despite the use of different devices [3], was easier to submit to a standardization process [4]. The SPT is currently a wellestablished technique for the in vivo diagnosis of IgEmediated sensitization, but it is not always a reproducible technique due to numerous interfering factors [5]. The major inconvenience of the former skin scratch test is the associated skin trauma leading to false-positive results depending upon the type of device used and the strength applied by the

*Address correspondence to this author at the Discipline and Laboratory of Clinical Immunology, Department of Internal Medicine, Faculty of Medical Sciences, University of Campinas, São Paulo, Brazil; Tel: 5519 34635941; Fax: 5519 34555726; E-mail: celso@ docsystems.med.br health care professional to scarify the skin [6]. One of most commonly used devices to perform the skin scratch test is the blood lancet [7]. Blood lancets were not designed to scarify skin and were used upside-down to scratch the skin with their blunt base. Usually, the bottoms of the lancets are not adequately polished to provide a burr-free edge, which is what accounts for the production of actual trauma to the skin. In the chamber-scarification technique, the authors used the point of a needle to break the skin in a crisscross pattern before applying the allergen [8]. The literature suggests that the skin scratch test has been abandoned due to poor reproducibility, great discomfort and the possibility of residual pigmented or depigmented areas for some time afterwards $[9,10]$. Here, we propose an alternative method for performing skin testing using a modified skin scratch test technique called the skin scrape test (SST), which was developed to avoid the original inconveniences of the early skin scratch test and the current SPT. We describe this method in detail with the objective of providing a standard methodology both for daily clinical work and for use in multi-center studies in order to effectively determine the predictive value of skin tests [11]. To evaluate the accuracy 
of the SST, we compared it with the SPT. We performed the tests side by side and employed standardized allergens that patients had previously been diagnosed, by the quantification of specific $\operatorname{IgE}$ (s-IgE), as being sensitized to or not sensitized to. This accuracy study, which was performed as recommended by the GRADE approach [12] (Grades of Recommendation, Assessment, Development and Evaluation), allowed us to determine the sensitivity and specificity of the SST in this specific selected population using the s-IgE as a proxy of sensitization [13-15]. Patients were analyzed according to the presence or absence of medically diagnosed atopic diseases such as persistent rhinitis, asthma and/or atopic dermatitis. These conditions were chosen due to their particular association with IgE-mediated immune reactivity [16].

\section{METHODS}

\section{Study Design and Subjects}

The study was approved by the ethical review board of the University of Sorocaba registered at the Plataforma Brasil (CAAE 07453312.2.0000.5500), and it was conducted according to the principles of the Declaration of Helsinki. We examined 74 male and 88 female subjects ( 1 to 68 years, mean $26.1+/-18.3$ years). To evaluate the utility of the SST, we compared it with the SPT performed at the same time with the same allergen solution in patients previously diagnosed by serum s-IgE (CAP Systems Pharmica; results expressed as $\mathrm{kU} / \mathrm{L}$ ) as being sensitive or not to these allergens [17]. A group of atopic patients was used to study the sensitivity of the skin tests. This group was composed of 125 patients with s-IgE> $1.0 \mathrm{kU} / \mathrm{L}$ to at least one of three house dust mite (HDM) antigens (Dermatophagoides pteronyssinus, Dermatophagoides farinae and Blomia tropicalis). Some patients had increased s-IgE to more than one mite and were included in two or three analyses, totaling 208 pairs of tests. The control group consisted of asymptomatic subjects to study the specificity of the skin tests and was composed of 37 subjects with s-IgE $<0.35 \mathrm{kU} / \mathrm{mL}$ to at least one of the following five allergens: the three HDM mentioned above plus Aspergillus fumigatus and Hevea brasiliensis. In this group, 122 pairs of tests were performed.

\section{Skin Testing Methodology}

Glycerinated saline diluent was used as a negative control. Histamine sulfate $1 \mathrm{mg} / \mathrm{mL}$ was used as a positive control. The SPT and the SST were performed by trained and supervised health care professionals on the volar aspect of the forearm in adults and children and on the back of toddlers and babies after withholding antihistamines for at least 10 days. Babies were tested on a parent's lap. Toddlers were tested while they were seated over the table edge in front of their mother. The SPT was performed with a disposable sterile acrylic pricker with a 1-mm lancet over a blunt basis (Punctor $^{\circledR}$ purchased from Alko do Brasil). The pricker was introduced at a $90^{\circ}$ angle perpendicular to the skin, through allergen solution, retrieved after 5 seconds and then discarded. To scrape the skin, we used the bevel of a sterilized and disposable $18-\mathrm{G} 1 \frac{1}{2}(1.20 \times 40)$ hypodermic needle (standard bevel). The skin was not scraped with the needle's point. Its hub (allowing some flexibility in touching the skin) gently held the needle at a $10^{\circ}$ to $25^{\circ}$ angle. The health care professional scraped the skin with the help of the bevel's edge in only one direction. The bevel did not scrape the skin backwards, and its movement resembled a broom cleaning the floor. The objective was to wipe the most superficial epidermal layer instead of traumatizing or scarifying the skin. This movement was repeated approximately 3 to 6 times (depending on the skin thickness), until the health care professional observed a thin homogeneous desquamation or a slight hyperemia (see Video 1). If scraping occurred beyond this depth, a skin scratch test would be performed instead of an SST. The extension of the scraped area was irrelevant because the tested area depends on the diameter of the drop applied. The width of the scraped area measured at least $3 \mathrm{~mm}$ wide. The health care professional scraped all of the areas to be tested in a single step (a single needle was used to perform all of the tests). During the first scrape, the health care professional counted the number of movements necessary to produce desquamation and repeated the same procedure on other are as to perform a homogeneous test. Sometimes, the scraped area was hardly visible, and it was helpful to mark the areas with a dermographic pen prior to scraping. Good illumination in the procedure room was essential for the skin tests. The allergens solutions are applied after scraping. Optionally, after scraping and before applying the allergens, the health care professional can wait 15 minutes to observe an occasional dermographism that could invalidate the test. Disrupting the stratum corneum barrier by the SST makes the skin permeable to soluble allergens; however, they do not gain immediate access to reactive layers. Thus, unlike the SPT (in which allergen solution is directly introduced via a 1-mm lancet into the skin, thus allowing the immediate cleaning of the allergen solution), when performing the SST, the allergen solution remained on the skin to allow absorption until the final reading was made at 15 minutes. At this time, the wheal's longest diameter (WLD) was assessed. We perform a negative control to draw the cut-offs for positive and negative tests. A wheal reaction was defined as positive if the WLD was $\geq 3 \mathrm{~mm} 15$ minutes after the application of the allergen extracts and after the subtraction of each patient's reaction to the negative control $[10,18]$.

The SST is a more convenient technique for use in small children because it is painless and promotes fewer struggles than the SPT. Children usually struggle more during pricking than during scraping sessions. Most children do not struggle during dermographic marking or allergen application. Struggles are less inconvenient during scraping because allergens have not yet been applied. One can apply allergens during a calmer second step some minutes after scraping. Struggles during pricking (when the allergens are already on the skin) make the procedure more difficult due to the increased possibility of dislodgements of solutions and the mixing of allergens. In this case, it is more convenient to extend the steps, apply one allergen, prick and dry the solution immediately after the prick before the next allergen application. The possibility of recognizing dermographism before applying the allergen solution is a clear advantage of the SST over the SPT because in the SPT, the trauma associated with puncture may produce an immediate reaction that sometimes may be indistinguishable from the reaction produced by the allergen. 


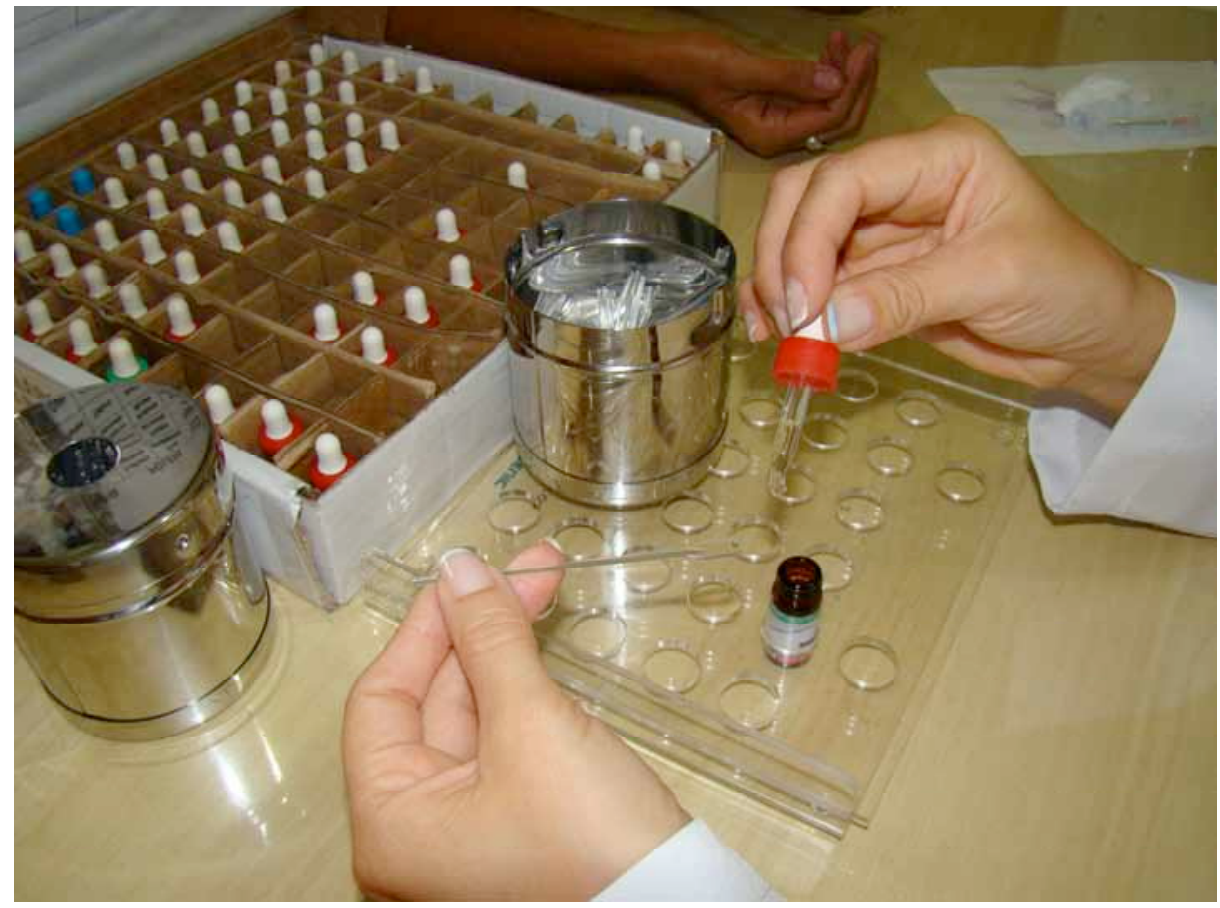

Fig. (1). Dropping of antigen extract solution onto the plastic antigen dispenser being applied to the scraped area. On the table are the container to keep the unused disposable dispensers (without cover) and the container to dispose the used dispensers (with a hole in the cover).

\section{Disposable Allergen Dispenser}

We used a disposable allergen dispenser to intermediate the allergen solution between the vial and the scraped skin. The allergen dispenser is a plastic spatula with an enlarged end where the allergen solution was dropped before being applied to the scraped area. Immediately after allergen application, this plastic dispenser was discarded. This procedure was also adopted for the performance of the SPT in order to standardize allergen application. The disposable allergen dispenser allows better visual control of the drop's size and avoids the waste of allergen solutions. To discard the dispenser; we used a steel container topped with a cover with a narrow hole to allow the health care professional to dispose of the dispenser but not to (unadvisedly) retrieve it. Another container (without a cover) holding unused dispensers was also available on the examination table (See Fig. 1).

\section{Statistical Analyses}

Group comparisons of the skin test outcomes were performed with paired and unpaired t tests. The data are reported as the arithmetic mean with $95 \%$ confidence intervals (CI). Box column graphs with 95\% CI whiskers were plotted between the means of the SPT WLD and the SST WLD. Paired correlation charts between the SPT WLD and the SST WLD were plotted, and the Spearman rank correlation was used to analyze the results.

Prospective contingency tables analyzed by Fisher's exact tests were used to compare the categorical diagnostic performance between tests [19].The sensitivity of the skin tests was calculated by grouping WLD results of $\geq 3 \mathrm{~mm}$ into a single categorical value. The specificity of the skin tests was calculated by grouping WLD results of $<3 \mathrm{~mm}$ in to a single categorical value. For all analyses, a p-value of less than 0.05 was considered statistically significant.
Statistical analyses were performed with GraphPad Prism for Windows (version 5.0; GraphPad Software, Inc., San Diego, CA, USA).

Schematic of the method of skin scrape test

\section{SCHEMATIC PRESENTATION OF THE METHOD OF SKIN SCRAPE TEST}

1. Be sure the patient is withholding antihistamines for at least 10 days.

2. Disinfection of the area (volar aspect of the forearm in adults/children and on the back of toddlers/babies).

3. Mark the area with demographic pen.

4. Scrape the area with the bevel of a $18-\mathrm{G} 1 \frac{1 / 2}{2}(1.20 \mathrm{x}$ 40) hypodermic needle (standard bevel) until the appearance of a thin desquamation or a slight hyperemia.

5. Optionally wait 15 minutes to observe occasional dermographism.

6. Apply the allergens and control solutions with help of the allergen dispenser over each scraped area.

7. Wait 15 minutes.

8. Dry the area with an absorptive paper.

9. Measure the wheal/erythema longest diameters.

10. Optionally mark the wheal with a demographic pen and transfer the mark to a graph paper with help of a transparent tape.

11. Wash the area. 
Table 1. Mean Wheal's Longest Diameter for the Skin Scrape Test (SST) and the Skin Prick Test (SPT) with Histamine Sulphate $1 \mathrm{mg} / \mathrm{mL}$ (Positive Control) and the Corresponding Allergen in Patients with s-IgE $>1.0 \mathrm{kU} / \mathrm{L}$ to Dermatophagoides pteronyssinus, Dermatophagoides farinae and Blomia Tropicalis

\begin{tabular}{|c|c|c|}
\hline & \multicolumn{2}{|c|}{ Mean Wheal's Longest Diameter } \\
\hline & SPT & $8.2 \mathrm{~mm}$ \\
\hline \hline D. pteronyssinus & $6.1 \mathrm{~mm}$ & $7.9 \mathrm{~mm}$ \\
\hline D. farinae & $6.5 \mathrm{~mm}$ & $4.8 \mathrm{~mm}$ \\
\hline Blomia tropicalis & $5.3 \mathrm{~mm}$ & $7.6 \mathrm{~mm}$ \\
\hline Average mean & $6.0 \mathrm{~mm}$ & $8.3 \mathrm{~mm}$ \\
\hline Positive control & $6.5 \mathrm{~mm}$ & \\
\hline
\end{tabular}

Table 2. Accuracy (Number of Positive Tests) Followed by the Percentage from Total (Sensitivity) and the False Negative Proportion of the Skin Scrape Test (SST), the Skin Prick Test (SPT) and Both Simultaneous Tests in Patients with s-IgE > 1.0 kU/L to Dermatophagoides pteronyssinus (D1), Dermatophagoides farinae (D2) and Blomia Tropicalis (RD201)

\begin{tabular}{|c|c|c|c|c|c|c|}
\hline & $\begin{array}{c}\text { SST } \\
\text { Accuracy } \\
\text { (Sensitivity) }\end{array}$ & $\begin{array}{c}\text { SST False } \\
\text { Negative } \\
\text { (Proportion) }\end{array}$ & $\begin{array}{l}\text { SPT Accuracy } \\
\text { (Sensitivity) }\end{array}$ & $\begin{array}{c}\text { SPT False } \\
\text { Negative } \\
\text { (Proportion) }\end{array}$ & $\begin{array}{c}\text { SST+SPT } \\
\text { Accuracy } \\
\text { (Sensitivity) }\end{array}$ & $\begin{array}{c}\text { SST+SPT False } \\
\text { Negative } \\
\text { (Proportion) }\end{array}$ \\
\hline $\begin{array}{c}\text { D1 } \\
\text { (92 tests) }\end{array}$ & $\begin{array}{c}83 \\
(90.2 \%)\end{array}$ & $\begin{array}{c}9 \\
(9.7 \%)\end{array}$ & $\begin{array}{c}81 \\
(88.0 \%)\end{array}$ & $\begin{array}{c}11 \\
(11.6 \%)\end{array}$ & $\begin{array}{c}88 \\
(95.5 \%)\end{array}$ & $\begin{array}{c}4 \\
(4.3 \%)\end{array}$ \\
\hline $\begin{array}{c}\text { D2 } \\
\text { (77 tests) }\end{array}$ & $\begin{array}{c}67 \\
(87.0 \%)\end{array}$ & $\begin{array}{c}10 \\
(12.9 \%)\end{array}$ & $\begin{array}{c}67 \\
(87.0 \%)\end{array}$ & $\begin{array}{c}10 \\
(12.9 \%)\end{array}$ & $\begin{array}{c}73 \\
(94.8 \%)\end{array}$ & $\begin{array}{c}4 \\
(5.2 \%)\end{array}$ \\
\hline $\begin{array}{l}\text { RD201 } \\
\text { (39 tests) }\end{array}$ & $\begin{array}{c}27 \\
(69.2 \%)\end{array}$ & $\begin{array}{c}12 \\
(30.7 \%)\end{array}$ & $\begin{array}{c}32 \\
(82.0 \%)\end{array}$ & $\begin{array}{c}7 \\
(17.9 \%)\end{array}$ & $\begin{array}{c}35 \\
(89.4 \%)\end{array}$ & $\begin{array}{c}4 \\
(10.2 \%)\end{array}$ \\
\hline $\begin{array}{c}\text { Total } \\
\text { (208 tests) }\end{array}$ & $\begin{array}{c}177 \\
(85.0 \%)\end{array}$ & $\begin{array}{c}31 \\
(14.0 \%)\end{array}$ & $\begin{array}{c}180 \\
(86.5 \%)\end{array}$ & $\begin{array}{c}28 \\
(13.4 \%)\end{array}$ & $\begin{array}{c}196 \\
(94.2 \%)\end{array}$ & $\begin{array}{c}12 \\
(5.7 \%)\end{array}$ \\
\hline
\end{tabular}

Table 3. The Skin Prick Test (SPT) and the Skin Scrape Test (SST) with the Corresponding Antigens According to Medical Diagnosis in Patients with s-IgE $>1.0 \mathrm{kU} / \mathrm{L}$ to Dermatophagoides Pteronyssinus, Dermatophagoides farinae and/or Blomia tropicalis

\begin{tabular}{|c|c|c|c|c|c|}
\hline Medical Diagnosis & $\begin{array}{c}\text { Mean Age } \\
\text { (Years) }\end{array}$ & $\begin{array}{c}\text { Mean } \\
\text { s-IgE } \\
\text { (kU/L) }\end{array}$ & $\begin{array}{c}\text { Positive to the } \\
\text { SPT (Sensitivity) }\end{array}$ & $\begin{array}{c}\text { Positive to } \\
\text { the SST } \\
\text { (Sensitivity) }\end{array}$ & $\begin{array}{c}\text { Positive to Both } \\
\text { SST and/or SSP } \\
\text { (Sensitivity) }\end{array}$ \\
\hline \hline $\begin{array}{c}\text { Atopic dermatitis } \\
\text { (79 tests) }\end{array}$ & 19.9 & 47.0 & $68(86.0 \%)$ & $48(93.6 \%)$ & $77(97.4 \%)$ \\
\hline $\begin{array}{c}\text { Asthma } \\
\text { (55 tests) }\end{array}$ & 18.6 & 40.3 & $46(83.6 \%)$ & $147.2 \%)$ & $51(92.7 \%)$ \\
\hline $\begin{array}{c}\text { Rhinitis } \\
(171 \text { tests) }\end{array}$ & 20.3 & 35.1 & $152(88.8 \%)$ & $162(94.7 \%)$ \\
\hline
\end{tabular}

\section{RESULTS}

Information on current rhinitis, asthma and atopic dermatitis was available for all subjects. The mean SPT positive control WLD was $6.5 \mathrm{~mm}$ (SD 2.7). The mean SST positive control WLD was $8.3 \mathrm{~mm}$ (SD 4.6). The mean SPT and SST allergens WLD in patients with s-IgE> $1.0 \mathrm{kU} / \mathrm{mL}$ to HDM are shown in Table 1. In this group, the sensitivity of the SST to detect HDM sensitization was $85.0 \%$ and the sensitivity of the SPT was $86.5 \%$ ( $p>0.05$ Fisher's exact test - see Table 2). Some patients did not react to the SPT but reacted to the SST, and others reacted to the SPT but did not react to the SST. Considering both tests analyzed together as a unique procedure, the sensitivity increased to $94.2 \%$. Table 3 presents the sensitivity of the SPT and the SST according to clinical diagnosis. Among the three conditions studied, a topic dermatitis showed better predictability by the SST alone (sensitivity of 93.6\%) and in association with the SPT (sensitivity of $97.4 \%$ ), but the differences with the other conditions were not significant using Fisher's exact test ( $p>$ $0.05)$. In the group of patients with $\mathrm{s}-\mathrm{IgE}<0.35 \mathrm{kU} / \mathrm{mL}$, the specificity of the SST was $90.1 \%$ and the specificity of the SPT was $72.9 \%$ ( $p>0.05$ Fisher's exact test). The specificity 
Table 4. Accuracy (Number of Non Reagent Tests) Followed by the Percentage from Total (Specificity) and False Positive Proportion of the Skin Scrape Test (SST), the Skin Prick Test (SPT) and both Simultaneous Tests in Patients with s-IgE < 1.0 kU/L to Dermatophagoides Pteronyssinus (D1), Dermatophagoides Farinae (D2), Blomia tropicalis (RD201), Aspergillus fumigatus (M3) and Hevea Brasiliensis (K82)

\begin{tabular}{|c|c|c|c|c|c|c|}
\hline & $\begin{array}{c}\text { Non-Reactive } \\
\text { to the SST } \\
\text { (Specificity) }\end{array}$ & $\begin{array}{c}\text { SST False } \\
\text { Positive } \\
\text { (Proportion) }\end{array}$ & $\begin{array}{c}\text { Non-Reactive to } \\
\text { the SPT } \\
\text { (Specificity) }\end{array}$ & $\begin{array}{c}\text { SPT False } \\
\text { Negative (Pro- } \\
\text { portion) }\end{array}$ & $\begin{array}{c}\text { Non-reactive to SST }+ \text { SPT } \\
\text { (Specificity) }\end{array}$ & $\begin{array}{c}\text { SST + SPT } \\
\text { False Positive (Proportion) }\end{array}$ \\
\hline $\begin{array}{c}\text { D1 } \\
\text { (28 tests) }\end{array}$ & $\begin{array}{c}26 \\
(92.9 \%)\end{array}$ & $\begin{array}{c}2 \\
(7.1 \%)\end{array}$ & $\begin{array}{c}19 \\
(67.9 \%)\end{array}$ & $\begin{array}{c}9 \\
(32.1 \%)\end{array}$ & $\begin{array}{c}19 \\
(67.9 \%)\end{array}$ & $\begin{array}{c}9 \\
(32.1 \%)\end{array}$ \\
\hline $\begin{array}{c}\text { D2 } \\
\text { (25 tests) }\end{array}$ & $\begin{array}{c}22 \\
(88 \%)\end{array}$ & $\begin{array}{c}3 \\
(12 \%)\end{array}$ & $\begin{array}{c}16 \\
(64 \%)\end{array}$ & $\begin{array}{c}9 \\
(36 \%)\end{array}$ & $\begin{array}{c}16 \\
(64 \%)\end{array}$ & $\begin{array}{c}9 \\
(36 \%)\end{array}$ \\
\hline $\begin{array}{l}\text { RD201 } \\
\text { (23 tests) }\end{array}$ & $\begin{array}{c}21 \\
(91.3 \%)\end{array}$ & $\begin{array}{c}2 \\
(8.7 \%)\end{array}$ & $\begin{array}{c}15 \\
(65.2 \%)\end{array}$ & $\begin{array}{c}8 \\
(34.8 \%)\end{array}$ & $\begin{array}{c}15 \\
(65.2 \%)\end{array}$ & $\begin{array}{c}8 \\
(34.8 \%)\end{array}$ \\
\hline $\begin{array}{c}\text { M3 } \\
\text { (26 tests) }\end{array}$ & $\begin{array}{c}24 \\
(92.3 \%)\end{array}$ & $\begin{array}{c}2 \\
(7.7 \%)\end{array}$ & $\begin{array}{c}20 \\
77 \%\end{array}$ & $\begin{array}{c}6 \\
23 \%\end{array}$ & $\begin{array}{c}20 \\
77 \%\end{array}$ & $\begin{array}{c}6 \\
23 \%\end{array}$ \\
\hline $\begin{array}{c}\text { K82 } \\
\text { (20 tests) }\end{array}$ & $\begin{array}{c}17 \\
(85 \%)\end{array}$ & $\begin{array}{c}3 \\
(15 \%)\end{array}$ & $\begin{array}{c}19 \\
95 \%\end{array}$ & $\begin{array}{c}1 \\
5 \%\end{array}$ & $\begin{array}{c}16 \\
(80 \%)\end{array}$ & $\begin{array}{c}4 \\
(20 \%)\end{array}$ \\
\hline $\begin{array}{c}\text { Total } \\
\text { (122 tests) }\end{array}$ & $\begin{array}{c}110 \\
(90.1 \%)\end{array}$ & $\begin{array}{c}12 \\
(10.9 \%)\end{array}$ & $\begin{array}{c}89 \\
(72.9 \%)\end{array}$ & $\begin{array}{c}33 \\
(27.1 \%)\end{array}$ & $\begin{array}{c}86 \\
(70.5 \%)\end{array}$ & $\begin{array}{c}36 \\
(29.5 \%)\end{array}$ \\
\hline
\end{tabular}

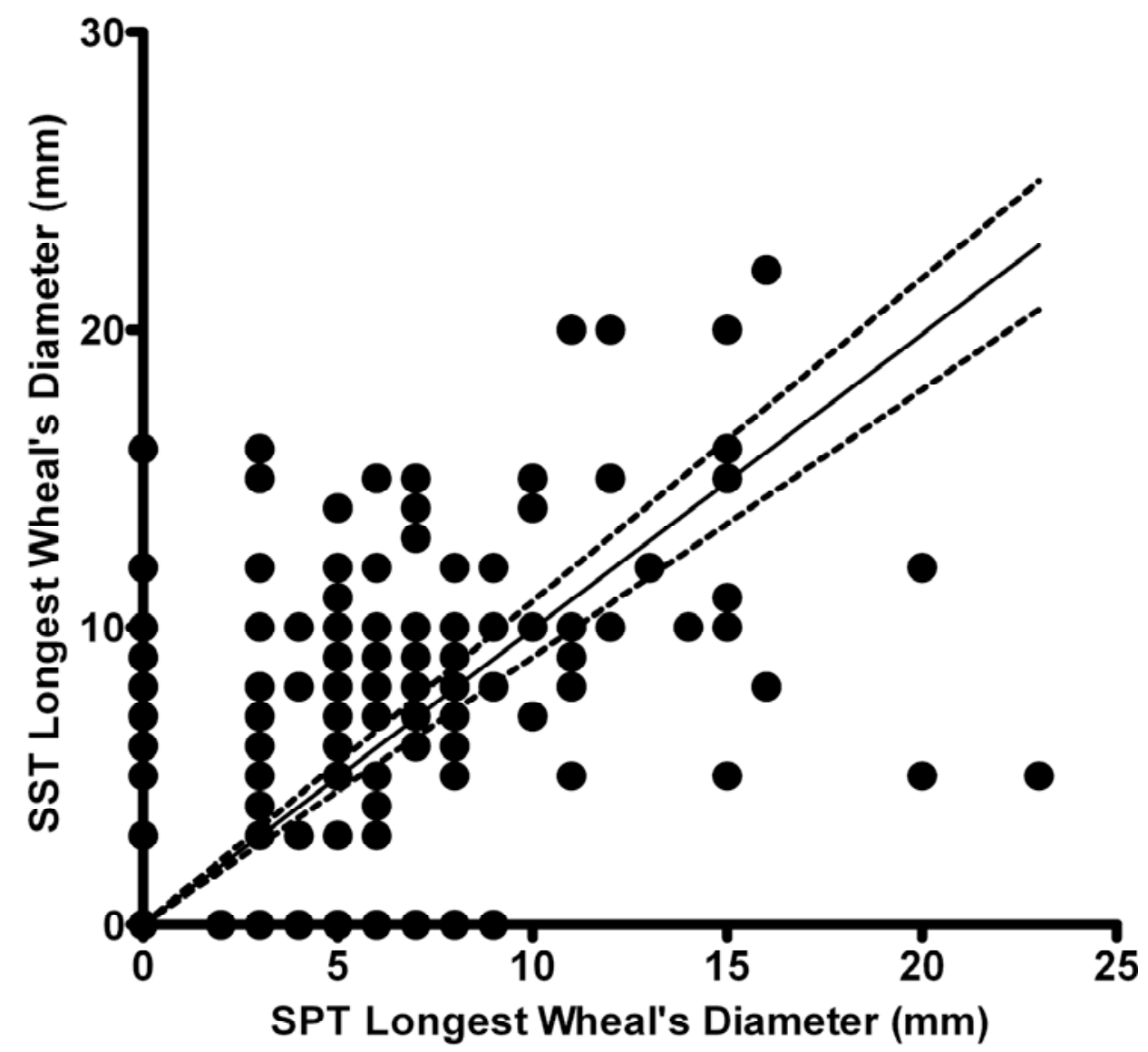

Fig. (2). Dispersion chart with 95\% CI for the linear regression with 208 XY pairs between the skin scrape test (SST) wheal's longest diameters plotted against the skin prick test (SPT) wheal's longest diameters for airborne allergens in patients with s-IgE $>1.0 \mathrm{kU} / \mathrm{L}$ to corresponding allergens. Spearman $r=0.40(0.27$ to $0.51 ; p<0.001)$.

of both tests analyzed together as a unique procedure was $70.5 \%$ (Table 4). Fig. (2) presents the dispersion chart with
95\% CI of the linear regression with $208 \mathrm{XY}$ pairs between the allergens SST WLD plotted against the allergens SPT 


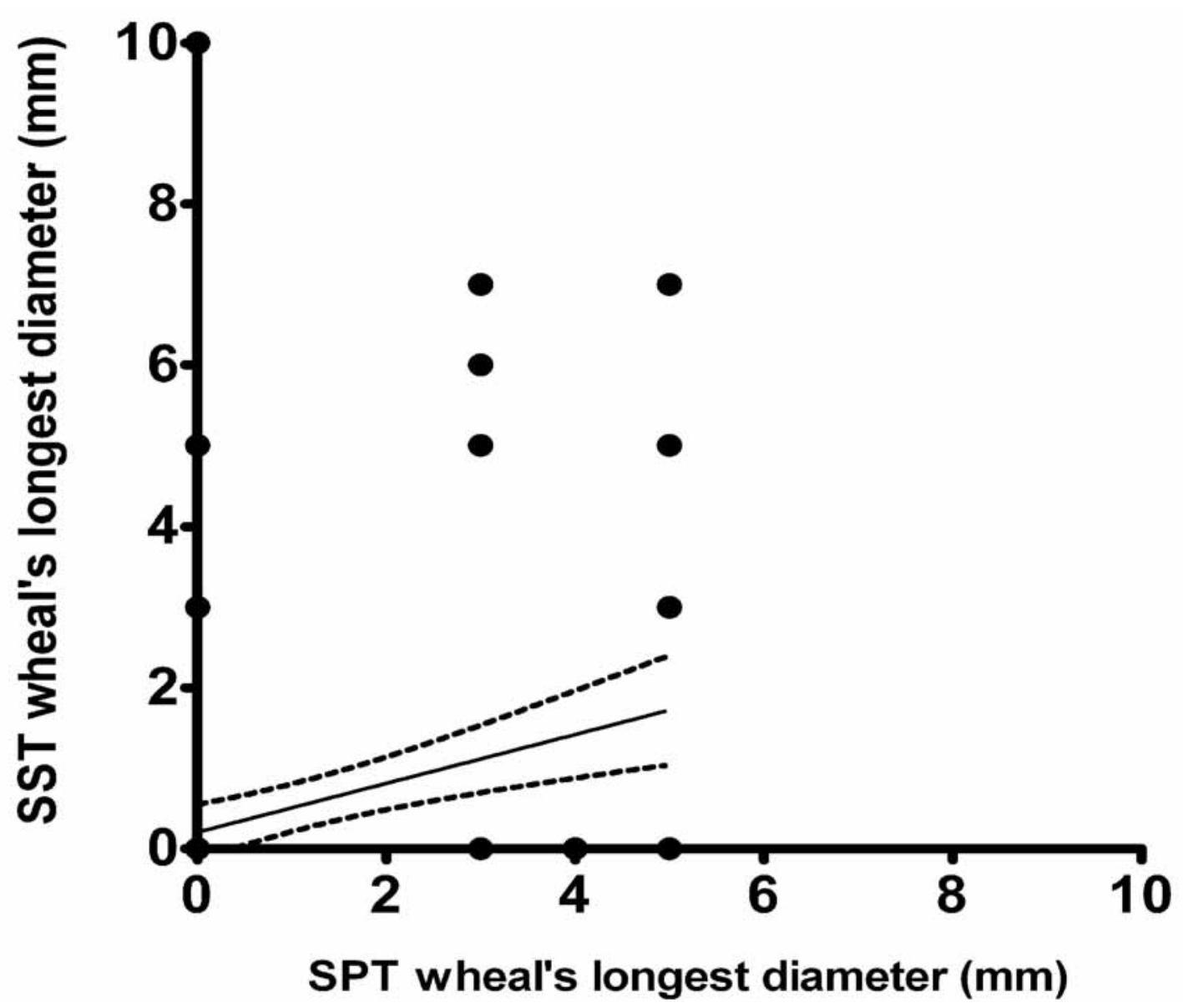

Fig. (3). Dispersion chart with 95\% CI for the linear regression with $122 \mathrm{XY}$ pairs between the skin scrape test (SST) wheal's longest diameters plotted against the skin prick test (SPT) wheal's longest diameters to airborne allergens in patients with s-IgE $<0.35 \mathrm{kU} / \mathrm{L}$ to corresponding allergens. Spearman $\mathrm{r}=0.37(0.20$ to $.51 ; \mathrm{p}<0.001)$.

WLD in patients with s-IgE> $1.0 \mathrm{kU} / \mathrm{mL}$ to $\mathrm{HDM}$ (Spearman $\mathrm{r}=0.40 ; 0.27$ to $0.51 ; \mathrm{p}<0.001)$. Fig. (3) presents the dispersion chart with $95 \%$ CI of the linear regression with $122 \mathrm{XY}$ pairs between the allergens SST WLD plotted against the allergens SPT WLD in patients with $\mathrm{s}-\mathrm{IgE}<0.35 \mathrm{kU} / \mathrm{mL}$ (Spearman $r=0.37 ; 0.20$ to $0.51 ; \mathrm{p}<0.001)$. The difference of the allergens mean WLD between the SPT $(6.0 \mathrm{~mm})$ and the $\operatorname{SST}(7.6 \mathrm{~mm})$ in patients with $\mathrm{s}-\mathrm{IgE}>1.0 \mathrm{kU} / \mathrm{L}$ was 1.6 $\mathrm{mm}$ ( 0.88 to $2.21 \mathrm{~mm} ; \mathrm{p}<0.001$ by paired $\mathrm{t}$ test). The difference of the allergens mean WLD between the SPT (1.10 $\mathrm{mm})$ and the $\operatorname{SST}(0.54 \mathrm{~mm})$ in patients with $\mathrm{s}-\operatorname{IgE}<0.35$ $\mathrm{kU} / \mathrm{L}$ was $0.56 \mathrm{~mm}(0.19$ to $0.93 \mathrm{~mm} ; \mathrm{p}=0.003$ by paired $\mathrm{t}$ test). Differences between the allergens mean WLDSST between the group of patients with $\mathrm{s}-\mathrm{IgE}>1.0 \mathrm{kU} / \mathrm{mL}$ and the group with $\mathrm{s}-\mathrm{IgE}<0.35 \mathrm{kU} / \mathrm{mL}$ was $7.07 \pm 0.44 \mathrm{~mm}$ (6.20 to $7.95 \mathrm{~mm} ; \mathrm{p}<0.001$ unpaired $\mathrm{t}$ test). Differences between the allergens mean WLDSPT between the group of patients with $\mathrm{s}-\mathrm{IgE}>1.0 \mathrm{kU} / \mathrm{mL}$ and the group with $\mathrm{s}-\mathrm{IgE}<0.35 \mathrm{kU} / \mathrm{mL}$ was $4.91 \pm 0.41 \mathrm{~mm}$ (4.15 to $5.76 \mathrm{~mm} ; \mathrm{p}<0.001$ by unpaired $\mathrm{t}$ test - see Fig. 4).

\section{DISCUSSION}

There is no perfect exam that can identify every single allergen responsible for every single symptom in every single allergic patient. Even the s-IgE measurement has issues con- cerning differences in accuracy between distinct techniques, and these are somehow resolved by means of skin testing [20]. Therefore, a careful clinical history performed by an experienced physician remains the best way to establish a reasonable link between the results of skin or blood tests and allergic disease $[21,22]$. A reactive skin test is a lead to be pursued by means of challenge tests to establish a diagnosis and to offer a proper therapy, or to remove the sources of the allergen [23]. In performing the SST, the skin is not scarified or broken. A needle's bevel is properly polished during its production in order to not present a reminiscent burr (unlike the primitive scarifies). The SST was perform to remove only the stratum corneum by sweeping the outermost skin layer that is largely responsible for the hydrophobic barrier function of the skin [24]. The stratum corneum has been described as a "brick-mortar wall" in which the terminally differentiated corneocytes (bricks) are embedded in the continuous matrix of specialized lipids (mortar). These lipids provide the essential element for the water barrier, while the corneocytes protect against physical injury [25]. Before the mid-1970s, the stratum corneum was thought to be biologically inert, but it is now appreciated to be both metabolically active and interactive with the underlying cell layers [26]. The simple removal of the impermeable barrier is enough to allow allergen penetration into adjacent skin layers without the need for deeper scarification. In order to remove the stra- 


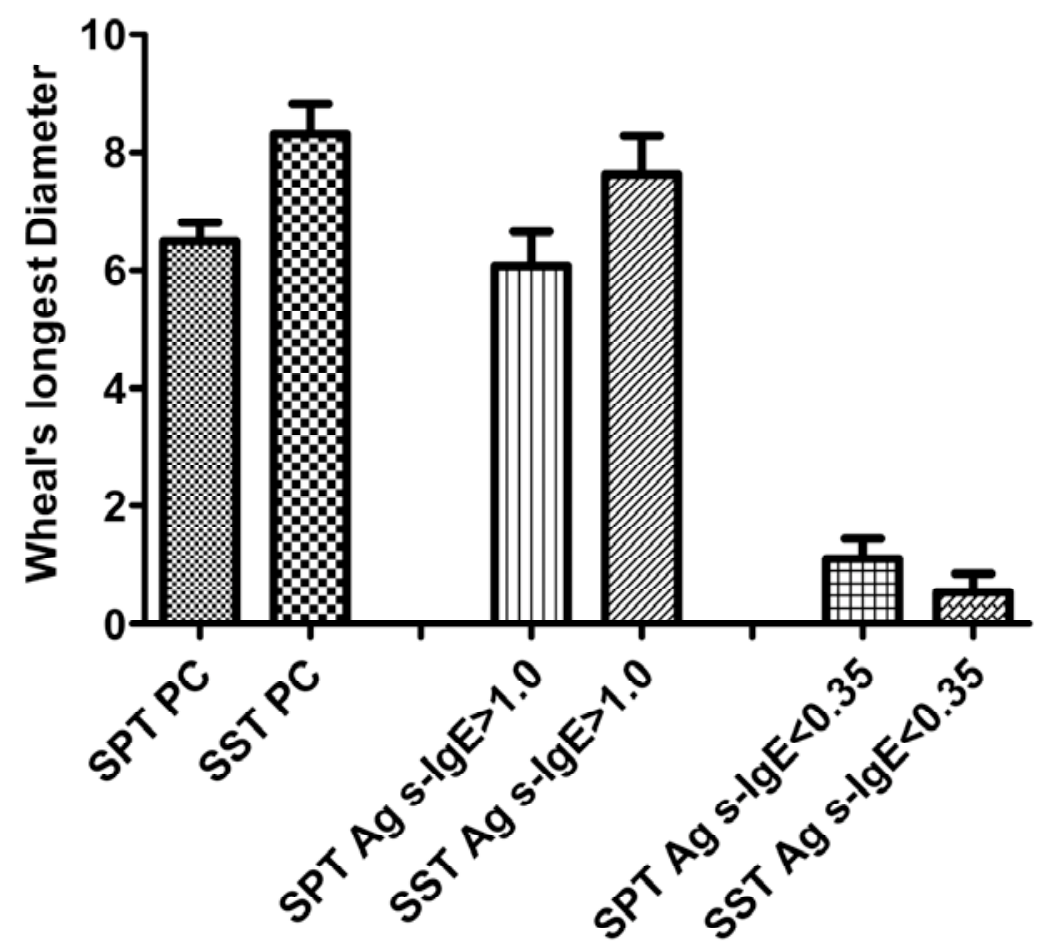

Fig. (4). Box column graphs with 95\% CI whiskers plotted with the mean of the skin prick test (SPT) and the skin scrape test (SST) positive control (PC) mean wheal's longest diameter; SPT and SST allergens (Ag) mean wheal's longest diameter in patients with s-IgE> $1.0 \mathrm{kU} / \mathrm{L}$; and the SPT and the SST allergens (Ag) mean wheal's longest diameter in patients with s-IgE< $0.35 \mathrm{kU} / \mathrm{L}$.

Table 5. Comparative Features of Skin Scrape Test and Skin Prick Test

\begin{tabular}{|c|c|c|}
\hline & Skin Prick Test & Skin Scrape Test \\
\hline \hline Number of skin devices & One for each tested allergen & One for all tested allergens \\
\hline Discomfort & Pain full for toddlers and babies & $85 \%$ \\
\hline Dermographism & May be recognized only in negative control & May be recognized on each test before applying the allergens \\
\hline Sensitivity & $86.5 \%$ & $90.1 \%$ \\
\hline Specificity & $72.9 \%$ & 9 \\
\hline
\end{tabular}

tum corneum as a preparation for patch testing for type IV allergy some centers routinely used tape stripping procedure with normal adhesive tape that is affixed and removed from the skin between one and ten times depending on the proband's skin type. We tried to perform this methodology, but it did not result in appreciable immediate skin reactions. We think that the residual glue left by the tape may diminishes skin permeability and be an interferent to the test.

The SSP was effective in demonstrating skin reactivity in some patients with the presence of s-IgE and who had a nonreactive SPT to HDM. On some occasions, we observed an inverse pattern with patients reacting to the SPT but not to the SST. Individual differences in the affinity threshold for IgE-allergen binding [27] may explain this phenomenon, as well the selective competition between immunoglobulins, which promote variable results to binding allergen affinity and skin tests [28]. For these reasons, some authors recommend performing an intradermic test to confirm a nonreactive SPT in a patient with a strong suggestive history of hypersensitivity to a particular allergen [29]. As the SST and the SPT are mutually complementary, the use of the other technique when the first does not react may spare the indication of the more traumatic and risky intradermic test. This is especially valuable when testing for food allergies because intradermic tests are usually not recommended for food allergens due to their association with an unacceptable rate of false-positive reactions [30]. The possibility of another "percutaneous" [31] technique that may be performed before the "intracutaneous" technique is very convenient because one can use the same allergen solution for the SPT and for the SST, while the intradermic test requires a non-glycerinated, more diluted and rigorously sterilized solution [9].

Another advantage of the SST is that it is less expensive than the SPT, as the health care professional may apply all antigens using a single hypodermic $18-\mathrm{G} 1 \frac{1}{2}$ needle available in most medical units (Table 5). To perform the SPT, one needs a disposable pricker for each tested antigen. In addition, the plastic dispenser saves the allergen solutions. With practice, the support provided by the plastic dispenser allows the health care professional to decrease the volume of the antigen solution applied to the skin. A standard drop applied directly with the dropper over the skin weighs an aver- 
age of $0.035 \mathrm{~g}$. The drop applied with the help of the dispenser weighs an average of $0.002 \mathrm{~g}$. Despite the lower volume applied to the skin, there was no significant reduction in the wheal reading of the SPT or the SST. The wheals produced by the SST were approximately $2 \mathrm{~mm}$ longer than the wheals produced by the SPT (Table 1). In fact, most of the solution applied to the skin during the SPT and the SST was discarding after the test because only a tiny fraction of the solution reaches the mast cells. Squire estimated that during a SPT, only $0.000003 \mathrm{~mL}$ was introduced into the skin [32]. This reduction in costs may be a great advantage in public health facilities where allergy testing is limited by lack of resources [33].

\section{CONCLUSIONS}

The skin scrape test performed with the antigen dispenser is an inexpensive, painless and suitable technique to demonstrate IgE-specific sensitization with similar outcomes to the skin prick test. It may be used as an alternative duplicate test to the skin prick test or may even be used as a primary triage test, though it is subject to further confirmation by the skin prick test, the intradermic test, specific-IgE measurements and/or challenge tests.

\section{CLINICAL IMPLICATIONS}

The skin scrape test is a modified skin scratch test, without the pitfalls of the original technique, able to diagnose allergic sensitization with accuracy similar to the skin prick test.

\section{CAPSULE SUMMARY}

The skin scrape test is described in details. Sensitivity is defined in patients with IgE-mediated a topic conditions and specificity is defined with help of subjects with undetectable $\mathrm{s}$-IgE to the studied antigens. The technique is compared with skin prick test.

\section{SUPPLEMENTARY MATERIAL}

Supplementary material is available on the publisher's web site along with the published article.

\section{CONFLICT OF INTEREST}

The authors confirm that this article content has no conflicts of interest.

\section{ACKNOWLEDGEMENT}

Declared none.

\section{REFERENCES}

[1] Blackley CH. Experimental researches on the causes and nature of catarrhus æstivus - Historical Digital ed. [Acessed July 2010] Available at: http://www.archive.org/stream/experimentalres00blacgoog Oxford: Oxford University 1873.

[2] Oppenheimer JJ. Devices for epicutaneous skin testing. Immunol Allergy Clin North Am 2001; 21(2): 263-72.

[3] Cohen SG, King JR. Skin tests a historic trail. Immunol Allergy Clin North Am 2001; 21(2): 191-249.

[4] Basomba A, Sastre A, Peláez A, Romar A, Campos A, GarcíaVillalmanzo A. Standardization of the prick test. Allergy 1985; 40(6): 395-9.

[5] Nelson HS. Variables in allergy skin testing. Immunol Allergy Clin North Am 2001; 21(2): 281-90.
[6] Dreborg S, Backman A, Basomba A, Bousquet J, Dieges P, Malling HJ. Methods for skin testing. Allergy 1989; 44(s10): 2230.

[7] Indrajana T, Spieksma FT, Voorhorst R. Comparative study of the intracutaneous, scratch and prick tests in allergy. Ann Allergy 1971; 29(12): 639-50.

[8] Frosch PJ, Kligman AM. The chamber-scarification test for irritancy. Contact Derm 1976; 2(6): 314-24.

[9] Oppenheimer JJ, Nelson HS. Skin testing. Ann Allergy Asthma Immunol 2006; 96(2): S6-12.

[10] Bernstein IL, Li JT, Bernstein DI, et al. Allergy diagnostic testing: an updated practice parameter. Ann Allergy Asthma Immunol 2008; 100(3 Suppl 3): S1-148.

[11] Clough GF, Lucas JSA. Reinventing the weal? Clin Exp Allergy 2007; 37(1): 1-3.

[12] Brozek JL, Akl EA, Jaeschke R, et al. Grading quality of evidence and strength of recommendations in clinical practice guidelines: Part 2 of 3 . The GRADE approach to grading quality of evidence about diagnostic tests and strategies. Allergy 2009; 64(8): 1109-16.

[13] Pastorello EA, Incorvaia $\mathrm{C}$, Ortolani $\mathrm{C}$, et al. Studies on the relationship between the level of specific $\operatorname{IgE}$ antibodies and the clinical expression of allergy: I. Definition of levels distinguishing patients with symptomatic from patients with asymptomatic allergy to common aeroallergens. J Allergy Clin Immunol 1995; 96(5): 580-7.

[14] Williams PB, Barnes JH, Szeinbach SL, Sullivan TJ. Analytic precision and accuracy of commercial immunoassays for specific IgE: establishing a standard. J Allergy Clin Immunol 2000; 105(6): 1221-30.

[15] Wang J, Godbold JH, Sampson HA. correlation of serum allergy (IgE) tests performed by different assay systems. J Allergy Clin Immunol 2008; 121(5): 1219-24.

[16] Illi S, Mutius E, Lau S, et al. The natural course of atopic dermatitis from birth to age 7 years and the association with asthma. J Allergy Clin Immunol 2004; 113(5): 925-31.

[17] Bousquet J, Chanez P, Chanal I, Michel FB. comparison between RAST and Pharmacia CAP system. A new automated specific IgE assay. J Allergy Clin Immunol 1990; 85(6): 1039-43.

[18] Pepys J. skin tests for immediate, type I, allergic reactions. Proc R Soc Med 1972; 65(3): 271-2.

[19] Simel DL, Samsa GP, Matchar DB. Likelihood ratios with confidence: sample size estimation for diagnostic test studies. J Clin Epidemiol 1991; 44(8): 763-70.

[20] Ollert M, Weissenbacher S, Rakoski J, Ring J. Allergen-specific ige measured by a continuous random-access immunoanalyzer: Interassay comparison and agreement with skin testing. Clin Chem 2005; 51(7):1241-9.

[21] Cox L, Williams B, Sicherer S, et al. Pearls and pitfalls of allergy diagnostic testing: report from the American College of Allergy, Asthma and Immunology/American Academy of Allergy, Asthma and Immunology Specific IgE Test Task Force. Ann Allergy Asthma Immunol 2008; 101(6): 580-92.

[22] Hagy GW, Settipane GA. Prognosis of positive allergy skin tests in an asymptomatic population. A three year follow-up of college students. J Allergy Clin Immunol 1971; 48(4): 200-11.

[23] Dreborg S, Lee TH, Kay AB, Durham SR. Immunotherapy is allergen-specific: a double-blind trial of mite or timothy extract in mite and grass dual-allergic patients. Int Arch Allergy Immunol 2012; 158(1): 63-70.

[24] Elias PM. Epidermal lipids, barrier function, and desquamation. J Invest Dermatol 1983; 80 Suppl: 44s-9.

[25] Harding CR. The stratum corneum: structure and function in health and disease. Dermatol Ther 2004; 17(s1): 6-15.

[26] Elias PM, Wood LC, Feingold KR. Epidermal pathogenesis of inflammatory dermatoses. Am J Contact Dermatitis 1999; 10(3): 119-26.

[27] Pierson-Mullany LK, Jackola DR, Blumenthal MN, Rosenberg A. Evidence of an affinity threshold for IgE-allergen binding in the percutaneous skin test reaction. Clin Exp Allergy 2002; 32(1): 10716.

[28] Jackola DR, Pierson-Mullany LK, Liebeler CL, Blumenthal MN, Rosenberg A. Variable binding affinities for allergen suggest a 'selective competition' among immunoglobulins in atopic and nonatopic humans. Mol Immunol 2002; 39(5-6): 367-77. 
[29] Nelson HS, Kolehmainen C, Lahr J, Murphy J, Buchmeier A. A comparison of multiheaded devices for allergy skin testing. J Allergy Clin Immunol 2004; 113(6): 1218-9.

[30] Chapman JA, Bernstein L, Lee RE, Oppenheimer JJ. Food allergy a practice parameter. Ann Allergy Asthma Immunol 2006; 96(3 Suppl 2): S1-68.

[31] Turkeltaub PC. Percutaneous and intracutaneous diagnostic tests of IgE-mediated diseases (immediate hypersensitivity). Clin Allergy Immunol 2000; 15: 53-87.
[32] Stenius B. Skin and provocation tests with Dermatophagoides pteronyssinus in allergic rhinitis. Comparisson of prick and intracutaneous skin test methods and correlation with specific IgE. Allergy 1973; 28(2): 81-100.

[33] Stingone JA, Claudio L. Disparities in allergy testing and health outcomes among urban children with asthma. J Allergy Clin Immunol 2008; 122(4): 748-53.

Received: February 10, 2013

Revised: March 02, 2013

Accepted: March 13, 2013

(C) Olivier et al.; Licensee Bentham Open.

This is an open access article licensed under the terms of the Creative Commons Attribution Non-Commercial License (http://creativecommons.org/licenses/by-nc/3.0/) which permits unrestricted, non-commercial use, distribution and reproduction in any medium, provided the work is properly cited. 